The chief scientist at Hadron Advanced Biosystems (Alexandria, VA, USA) is Ken Alibek, the former second-in-command of Russia's bioweapons project, who defected to the USA in 1992. He has discovered two ways to block anthrax in its later stages. One is to inhibit anthrax's protective antigen; the other is to block the bacterium's second punch, the lethal factor protein, one of two crucial infective parts of the bacterium, from causing its toxic effects. In addition, Hadron has identified an antibiotic that has greater activity against the bacterium than the current first-line antibiotics, and has further identified five haemolytic Bacillus anthracis proteins that, when inactivated, prevent a productive infection from becoming established. Xenerex Biosciences (San Diego, CA, USA), a subsidiary of Avanir, is developing neutralizing human antibodies to reduce the post-exposure damage caused by anthrax. Similarly, EluSys (Pine Brook, NJ, USA) is collaborating with the University of Texas in Austin, USA, and USAMRIID to develop heteropolymers to remove anthrax toxin from the bloodstream. The EluSys technology uses two monoclonal antibodies that are chemically linked, like a biological double-sided sticky tape. One antibody binds to the target to be removed - the anthrax toxin-and the second binds to a receptor on red blood cells, which then carry the pathogen to the liver to be destroyed. EluSys' first heteropolymer was tested last year in lupus patients, and chief executive officer Steven Sudovar believes that this technology could be used to treat other blood-borne viruses, bacteria, toxins and autoantibodies.

Biotech companies' efforts are also focusing on other pathogens: GenPhar (Mount Pleasant, SC, USA) is developing a multivalent vaccine against Marburg virus that was shown to produce neutralizing antibodies and cytotoxic $\mathrm{T}$ lymphocyte responses in animals. ID Biomedical (Vancouver, Canada) recently reported encouraging preclinical results with a proteasome-based plague vaccine: immunized mice developed high levels of antibodies in blood and respiratory fluids, and showed a high degree of protection against aerosoladministered plague. Hematech (Sioux Falls, SD, USA), supported by a $\$ 3.3$ million US government grant, is working on a bovine transgenic system for producing human polyclonal antibodies against botulinum neurotoxins.
A Ithough the US government's fight against bioterrorism is already helping to revitalize a depressed biotech market, others are not particularly happy with its effect on the way scientific research is carried out and made public, and, more importantly, which scientists are allowed to work in the USA. More than 60 substances that could potentially be used to create biological weapons have been given restricted-use status, and no scientist with a history of mental illness, drug conviction or from a nation considered to be a sponsor of terrorism can work with these materials. Scientists are concerned about these limitations made in the name of national security: The New York Times cited Lewis Branscom from Harvard University, who fears that barring certain individuals from research is reminiscent of 'witch-hunts' during the McCarthy era. The US National Academy of Science (NAS) issued a statement that "recent efforts by our government to constrain the flow of international visitors in the name of national security are having serious, unintended consequences for American science, engineering and medicine". And, in January, the NAS sponsored a meeting between scientists and security officials to discuss the censorship of data and restrictions on research. Meanwhile, George Poste, former head of R\&D at GlaxoSmithKline (Brentford, UK) and Chair of the US Department of Defense's Task Force on Defense Against Bioterrorism, emphasized the special dangers of 'dual use' technology - that which can be used both for drug development and to produce bioweapons. Gigi Kwik, of the Johns Hopkins Center for Civilian Biodefense Strategies (Baltimore, MD, USA), noted in Biosecurity and Bioterrorism $(\mathbf{1} ; 2003)$ that guidelines are being prepared to enable researchers to publish their work without giving away information that could be useful to a bioterrorist. But, although terrorists could potentially make use of public genome sequences, Claire Fraser, Director of the Institute for Genomic Research (Rockville, MD, USA), maintained that such sequences should remain in the public domain because these 'maps' are still relatively rough. Genomics should be used to identify and fight bioterrorism, not to restrict research, she said.

\section{Vicki Brower}

doi:10.1038/sj.embor.embor783

\title{
Feeding prejudice
}

\author{
Reluctance within the European Union to accept genetically modified \\ crops may hinder the benefits of this technology reaching the \\ developing world
}

T he words "impractical and unenforceable" were used by the European food and drink association, the CIAA, to greet the European Union (EU) legislation on the labelling of genetically modified (GM) food that is likely to become law later this month. The new ruling requires that all foods containing more than $0.5 \%$ GM produce are labelled as such. Controversially, the ruling extends this to all highly processed products derived from GM crops that no longer contain any traces of the dubious GM DNA or protein, such as oils. Critics fear that this will lead to an unnecessary paper trail for these goods, which is open to fraud and abuse as it cannot be based on simple detection methods. Although this may eventually lead to a lifting of the current EU ban on GM products imported from the USA, it will be a logistical nightmare for US producers as around $70 \%$ of the soybean and $30 \%$ of the maize that they grow is genetically engineered, and no such labelling of their downstream products is required. Not surprisingly, the USA are becoming increasingly frustrated with this cautious EU attitude, and it has caused further deterioration in what were already strained trade relations.

These new labelling laws are being hailed as a victory for the European consumer after numerous scare stories about GM crops. The flames of societal anxiety that these have created have been fanned by a prevailing wind of negative opinion 
in the news media, opposition by activist groups, a lack of reliable information on the current safeguards in place, a growing mistrust in industry and a general lack of awareness of how our food production system has evolved. In the developed world, Europe is essentially alone in its scepticism about genetic engineering. Outside the EU, crops enhanced by biotechnology are being grown on more than 130 million acres, most predominantly in the USA, Argentina, China and Canada, and food ingredients produced from these crops are found in thousands of products consumed worldwide. There is no unequivocal evidence of harm to our health or the environment, but there is still an intense debate about the value and safety of these crops. Indeed, the anti-GM lobby has been very successful in catching the media's attention, not least through one of their most ardent supporters, the heir to the British throne. In one of his many condemnations of the technology, Prince Charles warned in June 2002 that a price would be paid for pushing nature too far: "I think it's going to cause the most appalling problems [...] we're tampering with something fundamental, trying to redesign nature." These and other similar sentiments have reverberated around Europe and beyond, and have created an anti-GM mood that will be very difficult to reverse. $\mathrm{n}$ a continent of surplus, there is no obvious need for this technology. But it is a well-known fact that the world's population will hit 9 billion by the year 2050, and even as soon as 2020 there will be at least 1.5 billion more mouths to feed. This explosive increase in the world's population, along with the continuing deterioration of arable land, scarcity of fresh water and increasing environmental stress, pose serious threats to global agricultural production and food security. Clearly, the gains generated by the Green Revolution have hit a ceiling. The world's population now stands at 6 billion, and it is estimated that 800 million people are still undernourished. The potential of genetic engineering to produce more drought-resistant, disease-resistant and nutritious food must therefore place GM crops among what Jeffrey Sachs dubbed "Weapons of mass salvation" in the 24 October 2002 issue of The Economist.

Indeed, several crops have been engineered to increase their usefulness in Africa, South-East Asia and Latin America, including virus-resistant sweet potatoes, salt-tolerant tomatoes, metal-tolerant maize, trehaloseproducing rice to withstand drought and, possibly the most notorious, the pro-vitaminA-enriched 'golden rice'. One of its developers, Ingo Potrykus formerly from the ETH (Eidgenössische Technische Hochschule) in Zurich, Switzerland, firmly believes that this product can help to alleviate the suffering of

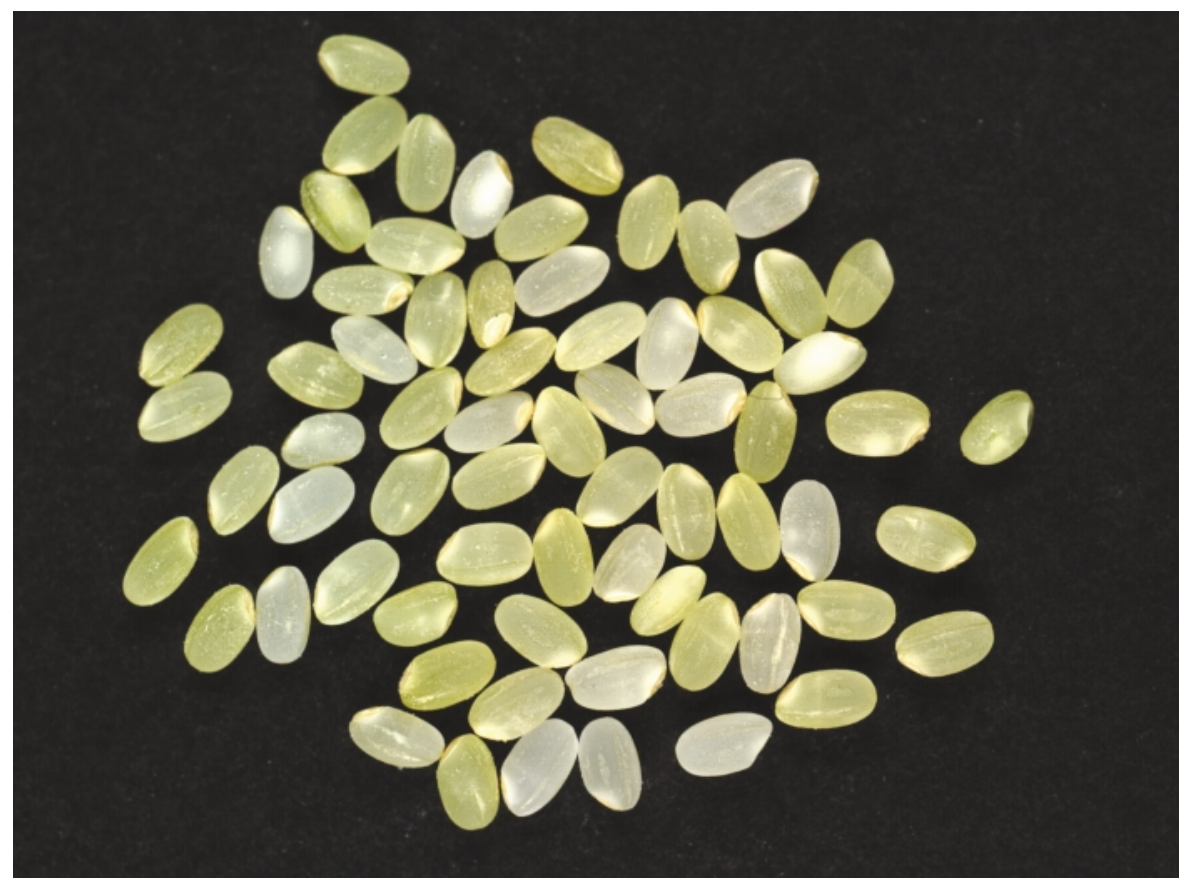

Golden rice. Courtesy of Peter Beyer, University of Freiburg, Germany.
In the developed world, Europe is essentially alone in its scepticism about genetic engineering...

the 400 million rice-eating poor who are deficient in vitamin A and, in particular, the 500,000 children who go blind every year as a result. "This was a crazy idea and everybody believed it would not work," he said at the European Plant Science Organisation conference in Brunnen, Switzerland, last October. With the support of the Rockefeller Foundation, it took Potrykus' group in Switzerland and Peter Beyer's group in Freiburg, Germany, nine years to develop golden rice, and it is now ready to be planted in farmers' fields. Unbeknown to them at the time, golden rice actually breaks 70 intellectual property rights, but on the whole, industry is co-operating, and these rights are in the process of being waived. However, as a GM crop, its introduction has met severe opposition, and it is now being subjected to rigorous testing. Named after its colour, which is due to the concentration of the vitamin A precursor $\beta$-carotene in the grains, the researchers estimate that only 100 grams a day will provide $50 \%$ of the recommended daily allowance of the vitamin. But this has been ridiculed by GM opponents who claim the figure is nearer an indigestible 9 kilograms a day. "Greenpeace are in the privileged situation where they can claim something and we have to do experiments to prove them wrong," said Potrykus. These particular experiments are due to be completed in 2004, but even then, there are still numerous hurdles to be jumped, and the unpredictable GM opponents to be persuaded, before the seeds can be provided free of charge and without limitations to the farmers, as planned. "Life is getting very difficult if you try and do something effective," he lamented. "It's better to stay with basic science."

7 he argument that GM food can feed the poor does not cut any ice with the opponents of this technology. They insist that there is enough food to feed the world's population and that the problem is simply one of distribution. "The fundamental reason why hunger persists relates to the fact that poor people lack money to buy food that is readily available or that they are deprived of access to, control over, or ownership of the productive resources necessary to produce it themselves," states the Five Year Freeze report (http://www.fiveyearfreeze.org) published in 


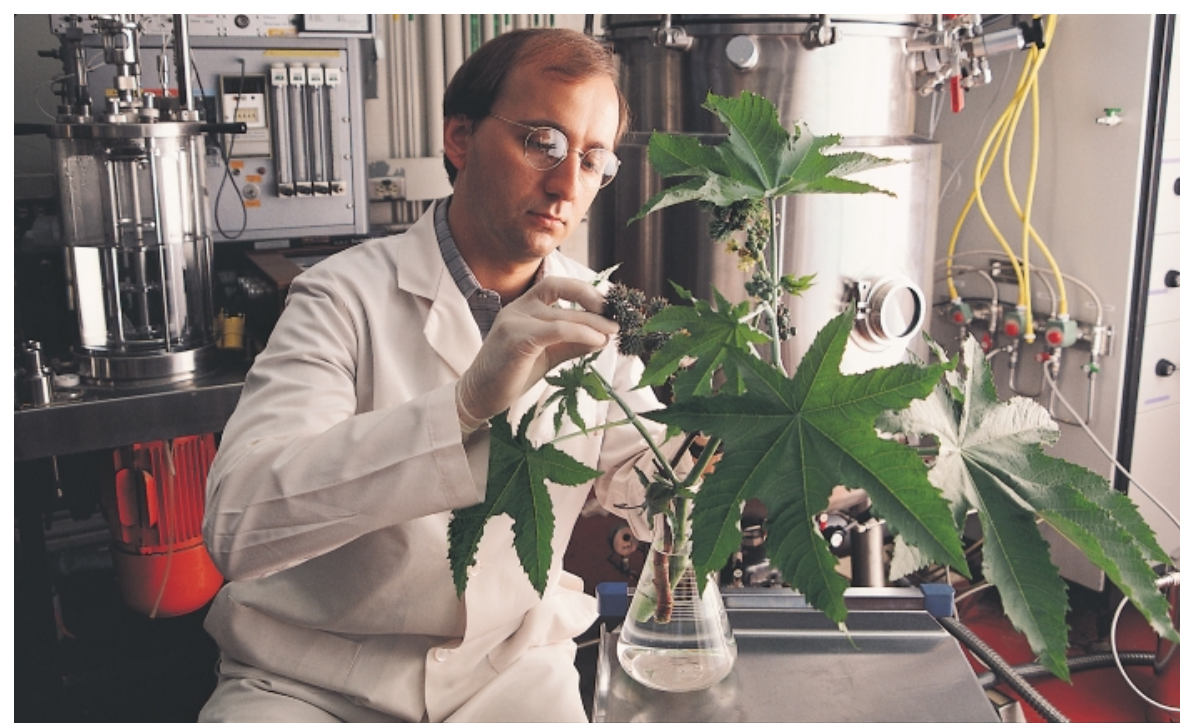

October 2002 and supported by 120 nongovernmental organizations (NGOs) including Greenpeace, Oxfam and Action Aid. "Without addressing this underlying problem, proponents of GM are avoiding the real causes of hunger and food insecurity," it concludes. Aina Edelman, representing the Norwegian Farmers and Smallholders Union at the EMBO members meeting in Oslo, Norway, last October, argued that GM crops prolong the use of monocultures, and maintained that changing people's diets is the only solution to malnutrition. "We need to have more diversity, not less, if we are going to meet food requirements. We need to encourage people to grow and eat a diversity of crops." Moreover, privately developed GM crops increase the dependency of farmers on industry, and snare the farmers into buying expensive seeds and chemicals from one harvest to the next. "True food security on an international level can only be achieved by food sovereignty on a local and national level." Ironically, GM crops, particularly if they were to be provided without industrial restrictions, could help to provide such sovereignty: for much of Africa, the poor live in rural areas where the agricultural potential is low and the natural resources are limited. Food must be locally produced in quantities that are sufficient and dependable, even on poor soil and in years when the environmental conditions are unfavourable.

NGOs such as Greenpeace have been very effective in stressing the potential risks that this technology poses to human health and the environment, and in highlighting that these have still not been adequately assessed. So effective, in fact, that the ripples of these protests have been felt in the developing world. When offered US aid in the form of GM maize to feed his starving population, Zambia's president Levy Mwanawasa said, "I would rather let my people starve than eat this toxic food." This globalization of fear has been rapid, but as GM technologies are being introduced at a speed that far outpaces the capacity of these developing countries to assess the risks and benefits, it is not surprising that they are taking their cue from Europe. Of course, this may ultimately lead to a rejection of this approach in the countries that could potentially benefit the most. And even if the principle of GM crops is accepted, there is still the governing issue of trade, as some farmers would not wish to grow produce that could not be exported to Europe. "The EU is not an island anymore. Biotech is not going to progress around the world if it stays this way," Channapatna Prakash from Tuskegee University, AL, USA, warned at the EPSO meeting.

$\mathrm{F}$ or GM crops to have a chance of being accepted throughout the world, therefore, a dialogue must be established with the public in EU countries to increase understanding and, more importantly, to gain their trust. Although there are links between knowledge and acceptance, these are far from one-to-one, and other factors come into play. In Denmark, for instance, public knowledge about GM crops is high, but acceptance is low, whereas in Spain the opposite is true. "It's not just understanding, it's how we bring about trust. Our increasingly affluent society is preoccupied with risk and has lost touch with agriculture," Prakash said. Moreover, scientists that are associated with this issue have quite an image problem, and are generally perceived by the public to be attached to industry, with all the self-serving intentions that this seems to imply. "There is a media fascination with maverick scientists. It is important that we have more activism to counter the misinformation," Prakash concluded. Michael Bevan from the John Innes Centre in Norwich, UK, believes that this cannot be done by scientists alone and that a conduit needs to be involved. "The message needs to come from someone the public trust. We must start to build networks with opinion leaders."

Change has always been difficult to accept, particularly in an area as emotionally charged as food. One major problem that needs to be overcome is the public's rather old-fashioned perception of the food production industry. The idyllic image of the cow roaming free on the Alps still persists, so it is hardly surprising that the sudden interference of biotechnology seems like a huge step away from this. In reality, genetic engineering is not so far removed from the processes that have previously been used to transform crops. Added to this is the mistrust caused by the speed with which the technology was introduced. According to Martin Frid from the Swedish Consumer Coalition, GM organisms (GMOs) were being discussed in the late 1980s, but "no-one predicted that one US company-Monsantowould introduce them onto the market so quickly." Effectively, the technology was introduced into the USA before legislation was in place, and this is held up in other countries as an unacceptable way forward, he continued. Helge Torgesen from the Institute of Technology Assessment, Vienna, Austria, puts this down to the fact that "innovations are not automatically welcomed here. There is less identification here with a 'Corporate Europe' than a 'Corporate US'." Not to mention the fact that the US population generally places much more trust in its regulatory bodies, such as the Food and Drug Administration (FDA) and the US Department of Agriculture (USDA).

\section{The world's population now stands at 6 billion, and it is estimated that 800 million people are still undernourished.}


Potrykus is still hopeful that golden rice will be accepted by farmers in developing countries, but knows that it will be an uphill battle that is essentially out of his hands. "It depends upon the political success of a radical anti-GMO lobby supported by an EU attitude," he said. Encouragingly, he has found that people in Europe are supportive of his development as people are truly concerned about the fate of blind children. "The public is not against the technology if they see a reason for it. In the EU, they don't see why they should accept a risk-if there is a risk-if there is no benefit." Equally, using the fate of poor farmers as 'emotional blackmail' for these crops to gain acceptance in the EU should be avoided. Torgesen warns that this message requires more sophistication. "Emotional appeals to save starving children are a bit hard to swallow and counterproductive as many people are turned off by such statements." Consequently, there needs to be 'a golden rice for Europe'. Bevan said, "We as scientists need to make it seem beneficial to the consumer. At the moment, it only benefits the producer. We need to make products that the public can see are valuable and can't be done any other way." Interestingly, recent research from the Broom's Barn Research Station

\section{"The public is not against the technology if they see a reason for it. In the EU, they don't see why they should accept a risk - if there is a risk-if there is no benefit."}

in Suffolk, UK, which was published online in January 2003 in Proceedings of The Royal Society of London, series B (www.pubs.royalsoc.ac.uk), indicates that GM herbicide-tolerant crops can be of benefit to the environment by increasing numbers of endangered wildlife. This, of course, must be balanced against the many reports that have suggested they have a negative impact on the environment (for a debate, see Trewavas \& Leaver, EMBO reports 2, 455-459 (2001); and Flothman \& van Aken, EMBO reports 2, 644-647 (2001)). Nonetheless, if genetic engineering can be shown to counteract certain trends about which society is concerned, the acceptance of GM crops is much more likely to be forthcoming.
With golden rice, the proof of principle has been established, and this technology could help to feed the poor and increase the nutritional quality of their food intake. To expect GM food to cure such a complex issue as world hunger is totally naive and unrealistic, but it is a potentially useful tool that should not be dismissed out of hand by more privileged countries. Unfortunately, the current focus of agricultural research funding is on high-technology approaches, which are designed to benefit large-scale industrial agriculture rather than the needs or interests of developing countries. Ingo Potrykus still hopes that one day it will be possible to assemble, in one variety of crop, a series of transgenic quality-traits such as provitamins, high-quality protein and high iron levels, combined with a series of agronomic traits such as pest and disease resistance. "But it must be done only by someone who can afford to be considered crazy," he said.

\section{Susan R. Owens}

doi:10.1038/sj.embor.embor785

\title{
DNA and consumer confidence
}

\author{
DNA fingerprinting and DNA-based labelling systems are gaining \\ importance in the security market to verify the authenticity of products
}

$\mathrm{n}$ the 1970s, the once-famous Italian redwine Chianti acquired a bad reputation for being cheap and often of low quality. Many wine makers had concentrated on quantity rather than quality and frequently mixed their must, the starting extract from grapes, with that of cheaper grapes from other regions of Italy. To regain the former standing of Chianti wines, in 1984 the Italian government issued the DOCG (Vino di origine controllata e garantita-Wines of controlled and guaranteed origin) label, which puts strict requirements on wine producers as to which grapes they are allowed to use for each quality of wine. The Chianti wine makers complied and, today, the reputation of the wine is restored. The policy also paid dividends as prices increased with quality - a premium Chianti Riserva from the Gallo Nero region between Florence and Siena now easily fetches $€ 40$ or more.
But the higher price of Chianti created a new problem: as prices rose, so did the temptation for unscrupulous fraudsters to use cheaper grapes and sell their wine under the Chianti label-a practice that wine producers everywhere face, be it in Italy, France or California. This does not necessarily pose a challenge for the expert, who can tell if a Spanish Rioja is made from the right grapes, said Javier Ibáñez from the Instituto Madrileño de Investigación Agraria e Alimentaria in Madrid, Spain. But it is more of a problem for the consumers and wine sellers who put their trust in what is stated on the bottle. Ibáñez's group is thus developing DNA fingerprinting as a means to identify grape varieties in must and bottled wines that would allow laboratories to verify a wine's content. Although this is not a problem at the moment for Spanish wines, he thinks that it is a worthwhile tool to have to hand. "I don't think that it is a major problem, but we anticipate that it may be in the

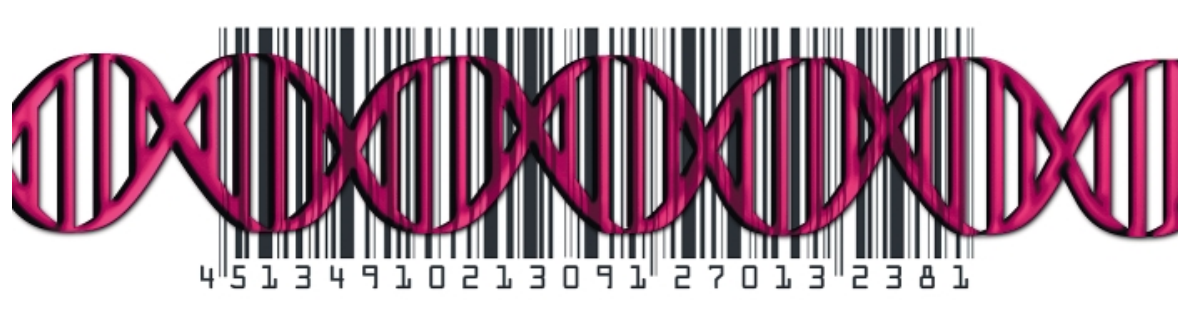

